\title{
The acute effects of different ankle taping techniques on dynamic balance and lower extremity jumping performance in professional soccer players
}

\section{Profesyonel futbol oyuncularında farklı ayak bileği bantlama tekniklerinin dinamik denge ve alt ekstremite sıçrama performansı üzerine akut etkileri}

\author{
Fatih Emre Doğan ${ }^{1}$ (D) Nevin Atalay Güzel ${ }^{2}$ iD \\ ${ }^{1}$ Department of Physiotherapy and Rehabilitation, Institute of Health Sciences, Gazi University, Ankara, Turkey \\ ${ }^{2}$ Department of Physiotherapy and Rehabilitation, Faculty of Health Sciences, Gazi University, Ankara, Turkey
}

\begin{abstract}
Objective: Different taping techniques are employed for improving functional performance. The aim of the present study was to investigate the effects of different ankle taping techniques on dynamic balance and lower extremity jumping performance in professional soccer players.

Materials and Methods: Twenty-four professional uninjured male soccer players were evaluated in four situations as no taping, placebo taping, kinesiologic-taping (KT), and dynamic-taping (DT). Taping techniques were performed in a randomized order with one-week intervals. All players were evaluated four times. Dynamic balance was evaluated with the Star Excursion Balance Test (SEBT). Jumping performance was assessed by using a single leg hop test and forward leap distances of the dominant foot were recorded.

Results: A significant difference was detected between applications concerning all the directions of SEBT ( $<<0.05)$. However, post-hoc comparisons revealed that these differences were between no taping and DT, and placebo taping and DT applications $(p<0.01)$. No difference was detected between applications related to lower extremity performance $(p>0.05)$.
\end{abstract}

Conclusion: DT technique might be preferred for improving dynamic balance in soccer players; however, none of the taping methods was found effective for enhancing lower extremity jumping performance.

Keywords: Athletic performance, postural balance, athletic tape

$\underline{\text { öz }}$

Amaç: Fonksiyonel performansı geliştirmek açısından farklı bantlama teknikleri kullanılmaktadır. Bu çalışmanın amacı profesyonel futbol oyuncularında farklı bantlama tekniklerinin dinamik denge ve alt ekstremite sıçrama performansı üzerine etkilerini incelemektir.

Gereç ve Yöntemler: Yaralanması bulunmayan 24 profesyonel erkek futbol oyuncusu bantlama yok, plasebo bantlama, kinezyolojik bantlama (KT) ve dinamik bantlama (DT) olmak üzere dört farklı durumda değerlendirildi. Bantlama teknikleri birer haftalık aralarla rastgele bir şekilde uygulandı. Dinamik denge Yıldız Denge Testi (Star Excursion Balance Test-SEBT) ile değerlendirildi. Sıçrama performansı tek bacak sıçrama testi ile ölçüldü ve dominant ayağın öne doğru sıçrama mesafesi kaydedildi.

Bulgular: SEBT'nin tüm yönleri açısından uygulamalar arasında anlamlı bir fark saptandı ( $p<0.05)$. Bununla birlikte, post-hoc karşılaştırmalar bu farkların, bantlama yok ve DT, plasebo bantlama ve DT uygulamaları arasında olduğunu ortaya çıkardı ( $<<0.01)$. Alt ekstremite performansı açısından uygulamalar arasında fark saptanmadı ( $\mathrm{p}>0.05)$

Sonuç: Futbolcularda DT tekniği dinamik dengeyi arttırmak için tercih edilebilir. Bununla birlikte, bantlama uygulamalarından hiçbiri alt ekstremite sıçrama performansını artırmak açısından etkili bulunmadı.

Anahtar Sözcükler: Atletik performans, postüral denge, atletik bantlama

\section{INTRODUCTION}

The ankle is one of the most injured body sections in many sports such as soccer, and ankle injuries compose about $25 \%$ of all sport-related injuries (1). Taping is a popular application among athletes that provides external support for injury prevention or during returning to sport (2). Many different tapes are available currently. While non-elastic tapes are used for limiting the movement, increasing stabilization

and unloading joints; elastic tapes are preferred due to their effects on muscle inhibition/facilitation and lymphatic drainage features $(3,4)$. Kinesiologic-taping (KT) and dynamic-taping (DT) are two methods which use elastic tapes. The KT tape is only stretched longitudinally, while the DT tape might be stretched both longitudinally and transver- 
sely, and this is the difference between the elastic tapes used in these two methods (5).

Many authors investigated the effects of different individual ankle taping methods on functional performance capacity including balance and strength parameters in both healthy and injured individuals (6). However, as to our knowledge, the effect of different ankle taping methods on dynamic balance and lower extremity jumping performance was not investigated previously. Therefore, the aim of the present study was to investigate the effects of different ankle taping techniques on dynamic balance and lower extremity jumping performance in professional soccer players.

\section{MATERIALS and METHODS}

The study was designed as randomized controlled and single blinded.

\section{Participants}

The present study was conducted with 24 male soccer players of a professional soccer club Osmanlıspor. Ethical approval was obtained prior to the study from Gazi University, Non-invasive Clinical Studies Ethical Committee under number 25901600-1734 on 17/04/2014.

The inclusion criteria were set as being 18-36 years, no history of lower extremity injury/surgery in last three months. Subjectswere excluded when they reported any unwillingness to participate in the study, an allergy to any taping, and any injury/discomfort during assessments. All the assessments were performed at the Health Center of Osmanlispor Soccer Club.

\section{Procedures}

The assessment days were set according to training and match schedule of the players. They were performed on the third dayfollowing the matches. All the players were assessed four times with one-week intervals. Four situations as without tape, placebo taping, KT and DT were tested randomly. Dominant sides were used for the assessments.

\section{Dynamic Balance}

Star Excursion Balance Test (SEBT) was used for assessing dynamic balance (7). Eight measuring tapes (each $150 \mathrm{~cm}$ long) were fixed on the floor with $45^{\circ}$ between each measuring tape to form a star shape. The player was randomly asked to reach in anterior, anteromedial, anterolateral, lateral, medial, posterolateral, posterior, and posteromedial directions. The player was allowed to reach four times to all eight directions for familiarizing (8). During the test, the player was positioned in the middle of the star on a single leg (dominant leg) with hands on the hips, and then he was asked to reach as far as possible in the asked direction with his contralateral leg. The distance reached was recorded in centimeters (Figure 1). Three attempts were performed for all the directions and the average of these three attempts was used for analysis. A 30-second rest was provided between attempts.
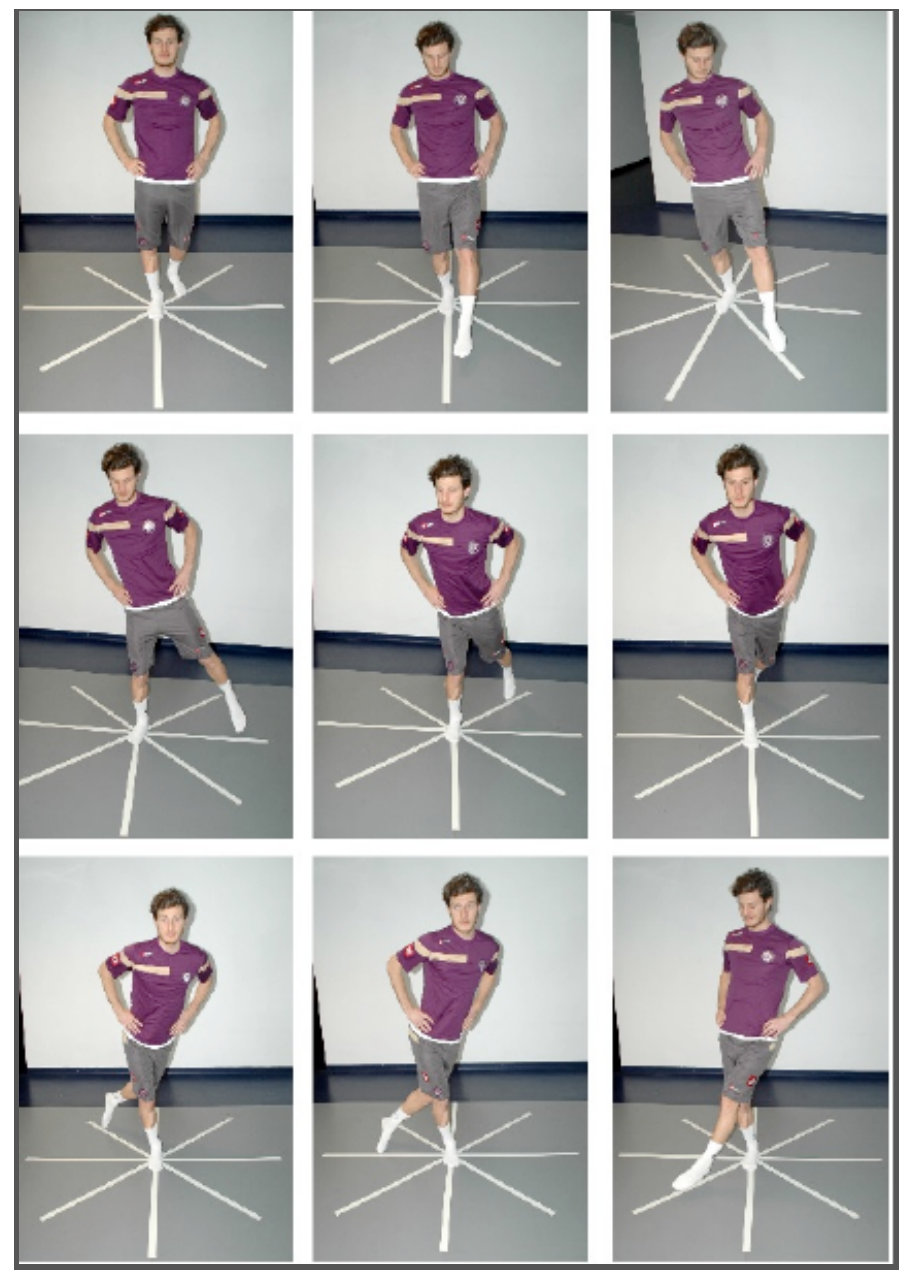

Figure 1. Star Balance Excursion Test

\section{Lower Extremity Performance}

A single leg hop test was used for assessing lower extremity performance. The reliability and validity of the test was reported previously (9). The player was positioned with his big toe on a line on the floor, while standing on his dominant foot. Then he was asked to jump forward as far as he can with the dominant leg, while his hands were on his waist. The test was accepted as uncompleted and was repeated in cases of getting help from the other foot or losing balance. Three attempts were performed by the player following a trial (Figure 2). The distance from the starting point to the landing point was measured, and the average of three attempts was used in the analysis. 


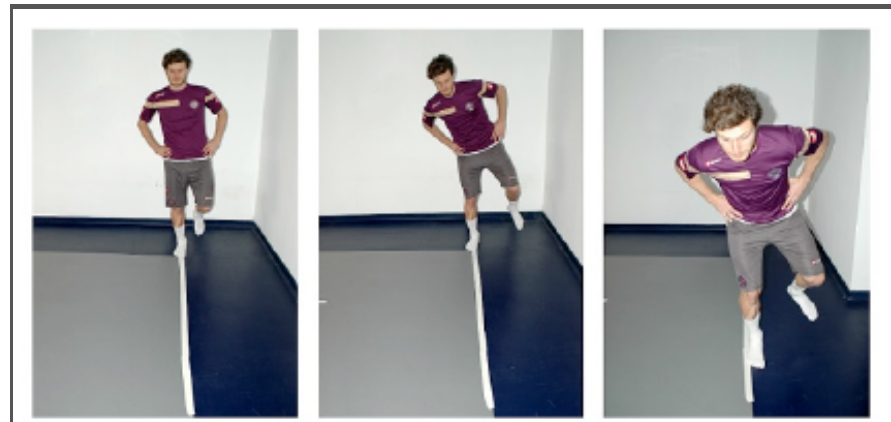

Figure 2. Single Leg Hop Test

\section{Interventions}

\section{Placebo taping}

The placebo taping was performed without using any stretching or technique. THOR Rigid Cohesive Tape (Mueller Sports Medicine, USA) was used for taping. Two parts of the tape was crossed in front of the ankle while the foot was in neutral position (Figure 3).

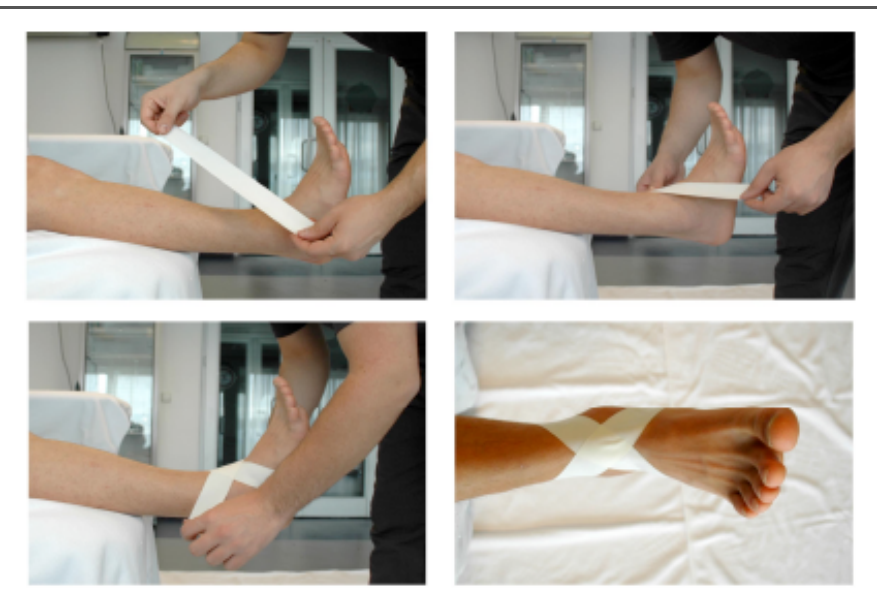

Figure 3. Application of placebo taping

\section{Kinesiologic-Taping (KT)}

Taping was performed by a certificated physiotherapist. Kinesiology tape (Mueller Sports Medicine, USA) was used for taping. Facilitation technique was used on the peroneal muscles to improve ankle stability, while the player was in supine position. For peroneus longus, taping was applied by placing the foot in dorsal flexion and inversion. Then, the foot was positioned in plantar flexion and inversion for peroneus brevis and the tape was passed posterior to the lateral malleolus and was fixed on fibula head without stretching (10). A third tape was used for stabilization (Figure 4).

\section{Dynamic-Taping (DT)}

A $15-\mathrm{cm}$ band was prepared by measuring from dorsum of the foot to above of the lateral malleolus. The part of the tape which was above the lateral malleolus was cut into a Y shape. The foot was positioned in dorsiflexion and eversi- on. Taping was started to be applied from dorsum of the foot to the sole of the foot without stretching. Then the stretching was set maximum for the part between the sole and lateral malleolus. The ends of the Y-shaped tape were applied on two different points such as peroneal muscles and medial of the tibia (Figure 5) (5).
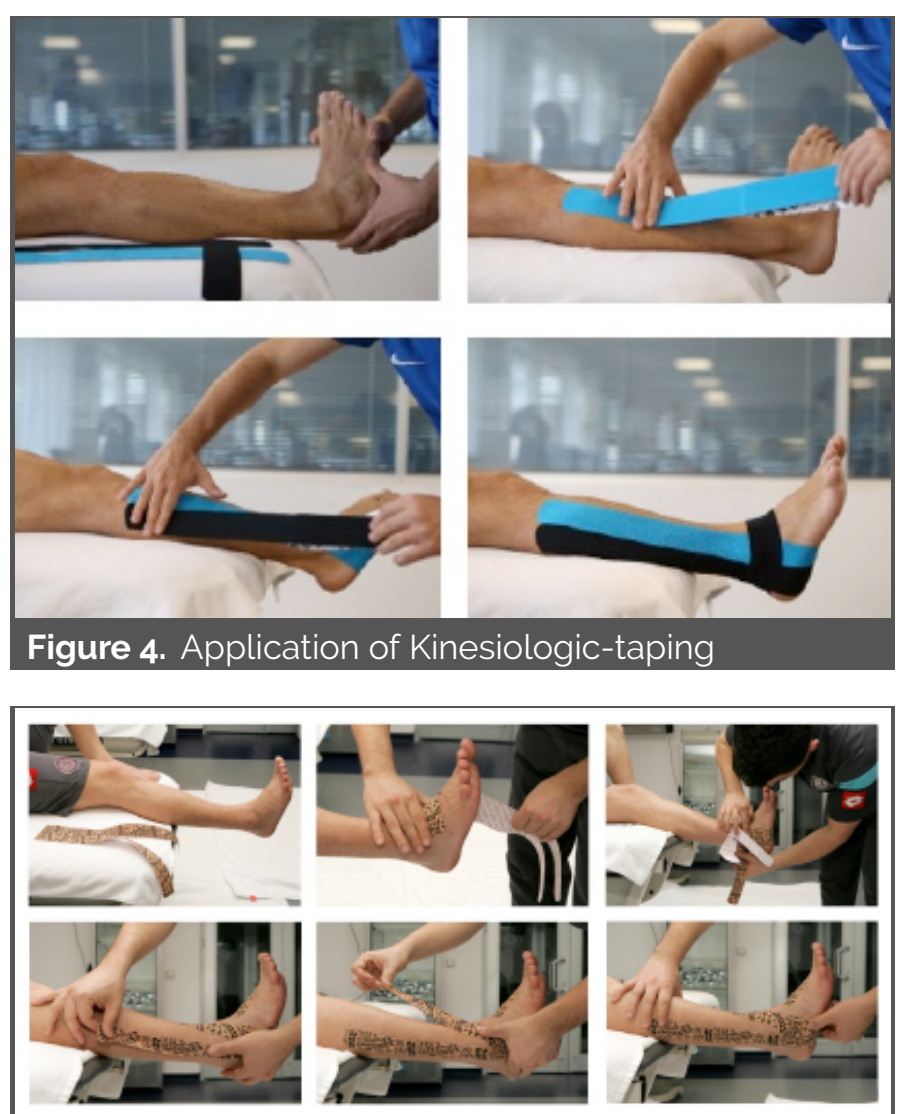

Figure 5. Application of dynamic taping

\section{Statistical Analysis}

Statistical analysis was performed by using "Statistical Package for Social Sciences" (SPSS) program version for IBM, 22.0 (SPSS Inc., Chicago, IL, USA). The normal distribution of the data was assessed by using histograms and the Shapiro-Wilk test. Mean \pm standard deviations and minimummaximum values were used for descriptive analyses. Nonparametric tests were fitted more adequate for statistical analysis. The Kruskal-Wallis test was performed to compare all the groups. Post-hoc analysis was performed by MannWhitney U Test using Bonferroni correction. Level of significance was set at $\mathrm{p}<0.05$ for the Kruskal-Wallis test, and at $\mathrm{p}<0.01$ for post hoc Mann-Whitney U test.

\section{RESULTS}

The study was completed with 24 professional male soccer players. Data including age, height, weight, and body mass index(BMI) is provided in Table 1. 
A significant difference was detected between applications concerning all the directions of SEBT (anterior: $\mathrm{p}=0.02$, anteromedial: $\mathrm{p}=0.02$, medial: $\mathrm{p}=0.02$, posteromedial: $\mathrm{p}=0.03$, posterior: $\mathrm{p}=0.02$, posterolateral: $\mathrm{p}=0.01$, lateral: $\mathrm{p}=0.04$, anterolateral: $\mathrm{p}=\mathrm{0.01}$ ). However, post-hoc comparisons revealed that these differences were between no taping and DT, and placebo-taping and DT applications ( $\mathrm{p}<0.01$ ) (Table 2). No difference was detected between applications related to lower extremity performance $(\mathrm{p}=0.17)$, thus no post-hoc analysis was performed (Table 2).

\section{Table 1. Descriptive data of the players}

$\begin{array}{lcc} & \mathbf{X} \pm \text { SD } & \text { Min-Max } \\ \text { Age (years) } & 20.0 \pm 3.2 & 18-30 \\ \text { Height }(\mathrm{m}) & 1.78 \pm 0.06 & 1.67-1.90 \\ \text { Body weight }(\mathrm{kg}) & 73.5 \pm 7.3 & 59-91 \\ \text { BMI }\left(\mathrm{kg} / \mathrm{m}^{2}\right) & 23.0 \pm 1.6 & 20.5-26.3\end{array}$

Table 1. Comparison of different taping methods on dynamic balance and lower extremity performance

\begin{tabular}{|c|c|c|c|c|c|}
\hline Group & No taping & Placebo taping & Kinesiologic taping & Dynamic taping & $n^{*}$ \\
\hline \multirow{2}{*}{$\begin{array}{l}\text { Parameter } \\
\text { SEBT }\end{array}$} & (NT) & (PT) & (KT) & (DT) & \\
\hline & $78.0(67.3 / 88.0)$ & $79.0(64.6 / 93)$ & $80.3(65.0 / 92.0)$ & $83.8(67.3 / 94.3)$ & $0.02^{*}$ \\
\hline \multirow{2}{*}{$\begin{array}{l}\text { Anterior } \\
\text { SEBT }\end{array}$} & \multicolumn{5}{|c|}{ p1:0.96 p2:0.56 p3<0.01** p4:0.61 p5<0.01** p6:0.02 } \\
\hline & $81.5(69.3 / 93.6)$ & $81.0(69.0 / 94.0)$ & $84.0(72.3 / 93.3)$ & $86.2(70.6 / 96.3)$ & $0.02^{*}$ \\
\hline \multirow{2}{*}{$\begin{array}{l}\text { Anteromedial } \\
\text { SEBT }\end{array}$} & \multicolumn{5}{|c|}{ p1:0.88 p2:0.48 p3:0.01 p4:0.43 p5<0.01** p6:0.04 } \\
\hline & $84.7(71.0 / 107.6)$ & $84.7(67.3 / 106.6)$ & $84.8(74.3 / 103.0)$ & $89.7(71.3 / 98.6)$ & $0.02^{*}$ \\
\hline \multirow{2}{*}{$\begin{array}{l}\text { Medial } \\
\text { SEBT }\end{array}$} & \multicolumn{5}{|c|}{ p1:0.82 p2:0.81 p3<0.01** p4:0.92 p5:0.01 p6:0.02 } \\
\hline & $86.5(75.0 / 107.0)$ & $87.8(76.3 / 111.0)$ & $88.8(74.6 / 105.6)$ & $91.8(80.0 / 104.6)$ & $0.03^{*}$ \\
\hline \multirow{2}{*}{$\begin{array}{l}\text { Posteromedial } \\
\text { SEBT }\end{array}$} & \multicolumn{5}{|c|}{ p1:0.96 p2:0.45 p3<0.01** p4:0.40 p5:0.01 p6:0.07 } \\
\hline & $91.2(80.3 / 100.3)$ & $91.3(77.0 / 108.3)$ & $93.0(81.6 / 102.0)$ & $95.5(88.3 / 111.6)$ & $0.02^{*}$ \\
\hline \multirow{2}{*}{$\begin{array}{l}\text { Posterior } \\
\text { SEBT }\end{array}$} & \multicolumn{5}{|c|}{ p1:0.99 p2:0.45 p3<0.01** p4:0.46 p5:0.01 p6:0.04 } \\
\hline & $81.1(71.6 / 96.3)$ & $82.0(70.3 / 103.3)$ & $84.7(73.6 / 97.6)$ & $89.2(77.6 / 103.6)$ & $0.01^{*}$ \\
\hline \multirow{2}{*}{$\begin{array}{l}\text { Posterolateral } \\
\text { SEBT }\end{array}$} & \multicolumn{5}{|c|}{ p1:0.70 p2:0.18 p3<0.01** p4:0.35 p5<0.01** p6:0.07 } \\
\hline & $70.3(56.0 / 86.6)$ & $71.2(58.6 / 90.0)$ & $75.0(59.0 / 88.3)$ & $76.3(61.0 / 91.6)$ & $0.04^{*}$ \\
\hline \multirow{2}{*}{$\begin{array}{l}\text { Lateral } \\
\text { SEBT }\end{array}$} & \multicolumn{5}{|c|}{ p1:0.66 p2:0.20 p3<0.01** p4:0.54 p5:0.05 p:0.13 } \\
\hline & $67.2(52.0 / 77.0)$ & $63.7(52.6 / 82.0)$ & $68.3(51.3 / 77.3)$ & $72.5(57.6 / 84.0)$ & $0.01^{*}$ \\
\hline Anterolateral & \multicolumn{5}{|c|}{ p1:0.19 p2:0.54 p3<0.01 ** p4:0.11 p5<0.01 ${ }^{* *}$ p6:0.04 } \\
\hline SLHT & 184.2 & 186.3 & 186.3 & 191.6 & 0.17 \\
\hline
\end{tabular}

Figures in $\mathrm{cm}$ as median (min-max); $\mathrm{n}=24$; SEBT: Star Excursion Balance test, SLHT: single leg hop test; ": Kruskal-Wallis test ( $p<0.05),{ }^{*}:$ Mann-Whitney $U$ test (p<0.01), p1: NT vs. PT, p2: NT vs. KT, p3: NT vs. DT, p4: PT vs. KT, p5: PT vs. DT, p6: KT vs. DT.

\section{DISCUSSION}

The present study was performed to investigate the effect of different taping techniques on dynamic balance and lower extremity jumping performance in uninjured (last three months) professional soccer players. Previous reports have investigated the effect of different taping methods on dynamic balance or lower extremity jumping performance (1012), however, no study was conducted to compare the effects of dynamic taping on these parameters with KT, to our knowledge. Therefore, the effectsof two different taping techniques were tested in four different situations as no taping, placebo taping, KT, and DT in the present study. According to our results, DT might help to improve dynamic balance compared with no taping or placebo taping. However, none of the taping methods were found effective in improving jumping performance.
Improving dynamic balance ability is not only important in soccer, but also in many sports (13). Therefore, researching new and better techniques are important for enhancing dynamic balance ability. Dynamic balance was assessed by using SEBT which was reported as a valid and reliable tool for athletes in various sports $(7,10,14)$. DT application was found superior to no taping and placebo taping related to SEBT results. DT was advocated as supporting joint biomechanics without limiting the range of motion, therefore leads improvements in dynamic performance. DT was suggested as an helping agent to transform potential energy to kinetic energy when it was applied according to muscle anatomy (5). However, while jumping performance was found to bebetter in the present study following DT, the difference was not statistically significant between taping applications. 
Other taping applications were not found effective in improving dynamic balance nor jumping performance in the present study. Confirming our findings, KT was not found effective on dynamic balance in some previous studies that employed a muscle technique similar to the present study $(10,15)$. However, Lee et al. mentioned that KT can improve dynamic balance, which was measured with SEBT in male soccer players with functional ankle instability (11). It seems that while KT may help in case of instability, it does not provide additional benefits in uninjured individuals. In addition, the one-way stretching ability of KT might contribute to this result by limiting the end-point motion of the ankle. However, this effect was not observed in DT which has two-way stretching features. Moreover, compared with no taping some insignificant decreases were observed following placebo taping where a rigid taping material was used.

Even though no studies investigated the same parameters in soccer players as in our study, other authors compared the effects of different taping methods on dynamic balance and lower extremity functionality. Briem et al. investigated the effects of KT, nonelastic sports tape and no taping during a sudden inversion perturbation in male athletes. These authors reported that nonelastic sports tape may enhance dynamic muscle support of the ankle; however, KT did not present similar results (12). Bicici et al. compared the effects of athletic taping and KT on functional performance in basketball players. They concluded that neither KT nor athletic tape had a statistically significant effect on dynamic balance that was measured by SEBT (10).

Some limitations exist related to our results. Firstly, only male soccer players were included in the present study. Gribble and Hertel has reported that male participants obtain better results in all the SEBT directions because of having longer stature and longer lower extremities in comparison to females (16). Therefore, only male soccer players were included in the present study. However, this limits the generalizability of our results. Nakajima et al. investigated the effect of KT on SEBT and reported that KT may help females to improve dynamic balance in certain directions (17). Moreover, all the players were uninjured athletes, and the results might be altered in athletes with chronic injuries. Some studies report bias related to learning effect in research thatinvestigate the acute effects of the interventions (18). Thus, a cross-over design randomization was employed to eliminate this bias.
In conclusion, it may be suggested that DT application might help preventing injuries in sports where contact and sudden movements occur, as in soccer. However, more researches using different taping methods, in different sports, and in different conditions such as chronic ankle instability or following a surgery are needed to reach firm decisions.

\section{Conflict of Interest / Çıkar Çatışması}

The authors declared no conflicts of interest with respect to authorship and/or publication of the article.

\section{Financial Disclosure / Finansal Destek}

The authors received no financial support for the research and/or publication of this article.

\section{REFERENCES}

1. Fong DTP, Hong Y, Chan LK, Yung PSH, Chan KM. A systematic review on ankle injury and ankle sprain in sports. Sports Med. 2007;37(1):73-94.

2. Bandyopadhyay A, Mahapatra D. Taping in sports: a brief update. J Hum Sport Exerc 2012;7(2):544-52.

3. Robbins S, Waked E, Rappel R. Ankle taping improves proprioception before and after exercise in young men. Br J Sports Med. 1995;29(4):242-7.

4. Fayson SD, Needle AR, Kaminski TW. The effects of ankle Kinesio taping on ankle stiffness and dynamic balance. Res Sports Med.2013;21(3):204-16.

5. McNeill W, Pedersen C. Dynamic tape. Is it all about controlling load? J Bodyw Mov Ther. 2016;20(1):179-88

6. Cordova ML, Ingersoll CD, Palmieri RM. Efficacy of prophylactic ankle support: an experimental perspective. J Athl Train. 2002;37(4):446-57.

7. Kinzey SJ, Armstrong CW. The reliability of the star-excursion test in assessing dynamic balance. J Orthop Sports Phys Ther. 1998;27(5):356-60.

8. Munro AG, Herrington LC. Between-session reliability of the star excursion balance test. Phys Ther Sport. 2010;11(4):128-32.

9. Ross MD, Langford B, Whelan PJ. Test-retest reliability of 4 single-leg horizontal hop tests. $J$ Strength Cond Res. 2002;16(4):617-22.

10. Bicici S, Karatas N, Baltaci G. Effect of athletic taping and kinesiotaping ${ }^{\circledR}$ on measurements of functional performance in basketball players with chronic inversion ankle sprains. Int J Sports Phys Ther. 2012;7(2): 154-66.

11. Lee $B G$, Lee JH. Immediate effects of ankle balance taping with kinesiology tape on the dynamic balance of young players with functional ankle instability. Technol Health Care. 2015;23(3):333-41.

12. Briem K, Eythörsdöttir H, Magnúsdóttir RG, Pálmarsson R, Rúnarsdöttir T, Sveinsson T. Effects of kinesio tape compared with nonelastic sports tape and the untaped ankle during a sudden inversion perturbation in male athletes. J Orthop Sports Phys Ther. 2011;41(5):328-35.

13. Paz GA, Gabbett TJ, Maia MF, Santana H, Miranda H, Lima V. Physical performance and positional differences among young female volleyball players. J Sports Med Phys Fitness. 2017;57(10):1282-9.

14. Willardson JM. Core stability training: applications to sports conditioning programs. J Strength Cond Res. 2007;21(3):979-85.

15. Parreira PdoCS, Costa LdaCM, Hespanhol LC Jr, Lopes AD, Costa LOP. Current evidence does not support the use of Kinesio Taping in clinical practice: a systematic review. J Physiother. 2014;60(1):31-9.

16. Gribble PA, Hertel J. Considerations for normalizing measures of the Star Excursion Balance Test. Meas Phys Educ Exerc Sci. 2003;7(2):89-100.

17. Nakajima MA, Baldridge C. The effect of kinesio ${ }^{\circledR}$ tape on vertical jump and dynamic postural control. Int J Sports Phys Ther. 2013;8(4):393-406.

18. Hopkins WG. Measures of reliability in sports medicine and science. Sports Med. 2000;30(1):1-15. 